\title{
INVESTIGATING THE EFFECT OF COVID - 19 PANDEMIC PROCESS ON FURNITURE USAGE FREQUENCY AND CONSUMER PREFERENCES
}

INVESTIGANDO EL EFECTO DE LA PANDEMIA DEL COVID-19 EN LA FRECUENCIA DE USO DEL MOBILIARIO Y LAS PREFERENCIAS DEL CONSUMIDOR

\author{
Ahmet Genc* \\ Rahim Merdan* \\ Isparta University of Applied Sciences
}

\section{Resumen}

Nuestro propósito en este estudio ha sido determinar cómo la pandemia COVID-19, que ha sufrido el mundo entero, afecta al mobiliario de jardín. Nuestra hipótesis antes de empezar a trabajar era ésta. Creíamos que la gente que estaba encerrada en sus casas durante la larga cuarentena tendría más interés por el mueble de exterior y de jardín. Por este motivo, llevamos a cabo una encuesta consistente en 30 preguntas para medir los hábitos de consumo. Se investigaron los datos sociodemográficos de 472 personas con diferentes niveles socioeconómicos para muebles de jardín y hábitos de uso durante la pandemia, a través de la aplicación de Google encuestas.

En nuestro estudio descubrimos el interés creciente derivado de la larga estadía en el hogar y que las personas deseaban renovar su mobiliario de jardín.

Palabras clave: Covid-19, pandemia, cuarentena, muebles de jardín, preferencias del consumidor

\section{Abstract}

The COVID-19 pandemic is an important issue that affects the whole world today. We investigated the reflection of consumer preferences in the furniture industry. Our purpose of doing this study is to identify how the COVID-19 pandemic, which affects the whole world, affects park and garden furniture preferences. Our hypothesis before we started the study was so; we had the opinion that people who stayed indoors/houses for a long time due to quarantine would increase their interest in park and garden furniture. For this purpose, we conducted a survey consisting of 30 questions to evaluate consumer habits. Within the scope of our research, the socio-demographic data of 472 individuals from different socio-economic (Lower / Middle / Upper) backgrounds were investigated for indoor and outdoor garden furniture and usage habits during the Covid-19 Pandemic period, by using Google surveys application. Survey technique was used to obtain research data.

In our study, we found that people's interest in nature has increased due to spending long times indoors because of the COVID-19 pandemic. We also 
found that people's desire to renew their park and garden furniture has increased due to quarantine.

Keywords: Covid-19, pandemic, quarantine, garden furniture, consumer preferences

\section{Introduction}

Health systems around the world have been struggling with the increasing number of cases of the viral respiratory syndrome first appeared in China since December $2019^{1}$. The cause of this disease is a new type of virus from the Coronavirus family and is called the novel Coronavirus (2019$\mathrm{nCoV}$ 1, SARS-CoV-2; and the disease that the new virus causes is called COVID-19 ${ }^{2}$.

In these days that we are struggling with COVID-19, there is a situation the society is experiencing: "being in quarantine"; and as a result of it, "physical isolation". According to the researches, quarantine has negative effects on our psychology. Emotions like intense anxiety, anger, or unexpected and unrealistic thoughts are some of those effects. Firstly, it is important to remember that these reactions are expected in such unusual situations. After that, recognizing stress factors and supporting sources in order to maintain this process in a mentally and physically healthy way, will be helpful. Being isolated or staying with the same people or objects for a long time can trigger stress as well. People who have experienced living under unusual circumstances, take attention to being tolerant to others and being able to be tolerated ${ }^{3}$.

The period of pandemic that we are in, has once again showed us the importance of the spaces we live in and the objects we use. Based on the hypothesis of living in isolated environments for a long time may have an effect on using objects, we aimed to investigate the interest of people on using garden furniture in the COVID-19 pandemic period. For that purpose, we tried to detect the tendency of customers by using surveys in Google Forms application. Our survey consisted of 30 questions. The purpose of our survey is to detect the socioeconomic data and the tendency of customers during the pandemic. We distributed our survey through online platforms such as WhatsApp, Instagram, Facebook and Gmail, and tried to detect people's preferences ${ }^{4}$. Unfortunately, we could not find enough articles in our literature search we conducted on this subject and this was our main limitation. We found a single article about Amazon customer preferences after the pandemic. However, there was no comparison regarding the prepandemic in that article. Only during the post pandemic process was the information that consumers preferred furniture products least. ${ }^{5}$

\section{The history of garden furniture}


The oldest gardens that were discovered in history is Hanging Gardens of Ziggurats (Babylon). There was a square shaped terrace on the top of pyramid bodied, inclined surfaced Ziggurats. They were dedicated to the sacredness of the sky, and also the clerics performed their astronomical studies in these monuments. In history, Ziggurats were followed by the ancient Greek gardens that were full of fruitful trees and plants. In those gardens, unlike today, fruits-vegetable, ornamental plants and flowers were grown together. The Roman Gardens were organized between walls ${ }^{6}$.

In Islamic World, the comprehension of gardens was based on creating a paradise and adornment the nature. Approaching gardens as a paradise symbol spreaded to Europe via the Crusades. In Medieval times, South France had some of the best gardens. The gardens at the place of Toulouse Count were considered the most flamboyant ones in Europe ${ }^{7}$.

In the XIV-XV centuries, when there were new thought and art movements, garden furniture started to gain more meaning and take new forms. Furnitures totally made by carving stones, started to decorate the gardens. They consisted two-seater benches, single seater armchairs, and tables ${ }^{8}$.

\section{Definition of garden furniture}

A garden is the place that completes the interior look with the exterior, and is beneficial space that people enjoy especially in good weather" "Garden furniture" are the objects that provides area for activities such as sitting, sleeping, conversation and eating, as well as convenience and comfort ${ }^{10}$.

\section{Types of garden furniture}

Among the furniture used in summer residences, garden furniture are particularly aesthetic and luxurious looking. Garden furniture need to be made of materials that are resistant to heat, humidity and other weather conditions ${ }^{11}$. Furnitures used in parks and gardens consist of tables, armchairs, chairs, coffee tables, sunbeds, sofas, benches etc. These furniture are used in taverns, coffeehouses, hotels and motel gardens, balconies, terraces; or in short, all types of outdoor and picnic areas ${ }^{12}$.

Garden Armchair: Garden armchairs, an indispensable element of gardens and terraces, can be produced from several different materials ${ }^{13}$. Armchairs, also known as chairs with armrests, are used in for longer periods of sitting and for resting purposes. They have cushions, and different materials can be used in their production ${ }^{14}$.

Garden Chair: Another essential piece of sitting part of gardens is chairs. They can be with or without armrests, as well as portable or not. Again, they can be made of many different materials and in different forms. All the materials used in garden armchairs are also used in garden chairs. Similarly, garden chairs are made of materials that are resistant to external 
factors (humidity, UV light, insects, etc.). Also additional protection can be $\operatorname{applied}^{15}$.

There isn't a high tendency to lean back on garden chairs. Because that comfort is provided by armchairs. In order to increase the comfort, $1-2 \mathrm{~cm}$ thick rubber covers can be put on sitting and leaning surfaces. It's not common to see sharp edges in garden chairs. It is almost impossible to come across flat and sharp edges in the plastic garden chairs produced in recent years. Just like any other garden furniture, garden chairs also have broad surfaces on the parts that contact the ground not to sink in ${ }^{16}$.

Garden Tables: One of the elements that play a role in garden joy is garden table. The tables that are used in gardens aren't as sumptuous or heavy as indoor tables. They're usually made of light materials. Portable and demountable ones are preferred for easy moving. Among garden tables; square, rectangle, round, ellipse tops are the most common ones ${ }^{17}$.

Garden tables, as its name tells, is used in outdoor areas such as gardens, balconies, terraces, poolsides and outdoor restaurants. Therefore they need to be made with consideration of different weather conditions such as rain and sun, and need to be lightweight and easily movable ${ }^{18}$.

Garden Coffee table: They provide connection between armchairs in sitting areas of gardens, and are more valuable than tables in terms of functionality. Their sizes, mobility, functionality and compliance with external factors are the positive sides of coffee tables. Their most significant feature is allowing people to take an object easily, without having to change their position, while relaxing. Therefore, they're usually placed next to sitting elements, especially armchairs, and are produced the same height as seats. Garden coffee tables are made of plastic, iron, bamboo and wood, and they can be in many different shapes. They usually present the features of the sitting element they belong to. It is important to pay attention that they're not heavy ${ }^{19}$.

Swing: Swings have a unique place among garden furniture. There are types with different lengths. The best swings are the ones that are made of Teak trees ${ }^{20}$.

Sunbeds: A sunbed or lounge-chair, which is used to rest on the sea and pool sides, balconies and terraces, is a seating element that can be adjusted according to the moving and lying positions. They are made foldable or stationary $^{21}$. There are many different types of sunbeds on the market. The base and foot sections can be adjusted as well as those that can be disassembled and fitted into a small single bed. White sea beds made of a special plastic seating can fit well in different colours cushions on the base where the beach umbrella is attached and lacquered tables and chairs. The most important wood material type is Teak tree. Other tree species can also be used ${ }^{22}$. 
Service Trolley: It is used to serve food and drinks in the garden. The front side usually has wheels and the backside doesn't. Tires are used on the tread of the wheels. The most important material used in the trolley is the Teak tree ${ }^{23}$.

There are many models of service trolleys that are very useful for organization companies and are indispensable for the hotel industry. While multi-tier trolleys are preferred in large organization events, small trolleys are preferred to facilitate service in large living spaces. It is also possible to see the service trolleys of all colours made of wood and metal. There are smaller and very stylish models used in cafes ${ }^{24}$.

Umbrellas: Outdoor umbrellas or patio umbrellas are designed not to be affected by sun rays, light rain or wind. High quality garden umbrella constructions are usually made of wood. There are different types of outdoor umbrellas such as garden awning, large patio umbrellas, wooden umbrellas, beach umbrellas and balcony umbrellas ${ }^{25}$.

Umbrellas with a wooden body are much more durable compared to the ones with an aluminium body. When these wooden umbrellas are used together with wooden furniture, they may form a crowded appearance. The points that should be considered in garden umbrellas are their body construction, fabric quality and feet. Feet of the umbrella should be appropriate for the length. The models with side curves are considered more useful $^{26}$.

Pergola: Especially in gardens with plenty of sun or in regions with a hot climate, shady areas must be created to protect against the burning heat of the sun. The pergolas and camellias that emerged as a result of this need, give the garden an aesthetic and more organized appearance ${ }^{27}$.

Pergolas and camellias can take various forms, they can be made of different materials; but whatever material is used, they must be robust enough to withstand the branches and leaves of climber plants that are fast growing. To provide that, the pergola should bear the weight of the plants, the pillars should be attached to the soil (50-70 cm deep) with concrete blocks. If the arbor rests against the wall, the beams must be attached with sturdy iron brackets ${ }^{28}$.

Pergola is the name given to shading elements made of wood or iron material, which can be covered with open top, semi-open or closed, in an organic structure (flat, circular or arc shaped) with the space. When the pergola is made of wood and ivy-style plants are wrapped on it, it provides a very organic, pleasant and natural appearance to the place. One can use wooden pergola easily in all outdoor areas ${ }^{29}$.

Hammock: Hammocks made of wooden material are generally made in two forms: V-shape and arc shape. Hammocks; It is made in $350-550 \mathrm{~cm}$ length, 120-160 cm height, 80-140 $\mathrm{cm}$ depth ${ }^{30}$.

Benches: They are complementary elements of private gardens, public parks, botanical gardens, picnic areas and the streets. The benefit of these 
elements is that they have the sitting and table parts together. There are instances where they are separate as well. Benches are roughly sized furniture due to their functions. They are durable structures, since they are outdoor and public goods. The joints should be made as solid as possible. Stone, marble, plastic, metal, wood, concrete, artificial wood materials are the most common fabrication materials ${ }^{31}$.

Benches, which are constantly exposed to damaging factors, should be produced to provide enough strength and durability ${ }^{32}$.

\section{Material - method}

In this study, we investigated garden furniture preferences and usage habits of 472 individuals from different socio-economic (Lower / Middle / Upper) backgrounds during the Covid-19 pandemic. Questionnaire technique was used to obtain data. The survey results obtained from 472 individuals by using social media tools were evaluated with $95 \%$ confidence level and $3 \%$ acceptable margin of error. In the questionnaire application, there were questions to investigate the different socio-demographic characteristics of furniture users and the factors that affect the choice of furniture. At the end of the study, the effect of the quarantine and pandemic period on the garden furniture preferences of the people was determined by the factor analysis method.

\section{Research Method}

We used a questionnaire method to measure furniture users' preferences during the pandemic period. In our country, different socio-economic (lower / middle / upper) level in 472 people in indoor and outdoor garden furniture preference, represents the best sampling method. The sample size was 472 . But as a research method, to reach more target audience; an "online form" was created from the forms section of the Google Drive web interface.

Survey data was collected by sending and sharing the access address of the created form via social media communication tools (e-mail, Facebook, Twitter, Instagram). 95\% of the surveys applied are included in the research. In the survey form, there were questions about sociodemographic status (gender, marital status, educational status, monthly income, location of residence, presence of the garden or terrace in the house), as well as questions related to the pandemic period (presence of an individual with Covid-19 infection in the immediate vicinity, how the pandemic affected the person's interest in garden furniture or in nature; in what areas the pandemic period was spent; presence of desire to buy any garden furniture during quarantine period; how the interest in outdoor furniture during pandemic period was affected)

We questioned the reasons for preferring garden furniture during the COVID-19 pandemic. For this purpose; the ease of transportation, comfort, functionality, physical (moisture, water absorption, etc) and mechanical 
(impact, abrasion and scratch) resistance of the furniture, the longevity of the furniture, whether the seller or family recommended it or not, whether the person preferred it due to recommendation or not, whether the person preferred it due to the quarantine experienced during the COVID-19 pandemic, whether the person preferred it due to the restrictions on social activities during COVID-19, whether the person preferred it because of the desire to spend time outdoors during COVID-19 were questioned. The purpose of asking all these questions was to investigate the reason for the preference of consumers.

Another question we asked the consumers was which areas they wanted to spend more time after the COVID-19 pandemic. The options we presented to the consumers in the survey were as follows: at home, on the balcony, on the terrace, outside, and "my preferences will not change". Our purpose was to question the change in preferences during the pandemic and quarantine period regarding the use of space. Likert scale (from one end to the other) was used for the answer of the questionnaire, and a method that measures attitudes and behaviours was used by using the changing response options of the consumers.

\section{Evaluation of the Data}

Various statistical techniques have been used to understand the data obtained in the research. The results of the survey conducted for this purpose were taken from the Google driver memory. Descriptive statistics and percentage frequency distributions were determined by using SPSS program. The findings were interpreted in the discussion section.

\section{Results}

The aim of this study is to determine the socio-demographic data of consumers and their tendencies in the pandemic process. First of all, we questioned the socio demographic data of individuals, residents' monthly income and settlements, educational status, and the effect of pandemic period on people's garden furniture preferences. For this purpose, the data obtained as a result of the survey results were evaluated. The numerical distributions resulting from this evaluation are shown in the tables and graphics prepared below.

According to our statistical analysis (Chi-Square Tests), people's desire to renew their living spaces was determined as a result of long time spent at home during both sex COVID-19 pandemics. Considering the desire to renew the living space, the increase rate in men is $34.5 \%$, while this rate is $65.5 \%$ for women, and it is seen that women want to renew their living space more (Table 1).

According to our statistical analysis (Chi-Square Tests), it was found that there was a significant relationship between people's interest in nature due to the long time spent at home during both sexes COVID-19 pandemics. 
Looking at the interest in nature, the rate of increase in men is $38.2 \%$, while this rate is $61.8 \%$ in women, and it is seen that women have more interest in nature (Table 2)

According to our statistical analysis (Chi-Square Tests), it was found that there was a significant relationship between marital status and interest in nature due to the long time spent at home during the COVID-19 pandemic. Considering the interest in nature, the rate of increase in married people is $63.9 \%$, while this rate is $36.1 \%$ in singles, and it is seen that married people have more interest in nature (Table 3).

According to our statistical analysis (Chi-Square Tests), the interest in garden furniture is $72.7 \%$ while there is no significant relationship with the residential area (city centres, smaller districts and rural areas) in the Covid19 pandemic period. It is seen that people living in the city centre are interested in garden furniture (Table 4).

According to our statistical analysis (Chi-Square Tests), it was found that there was a significant relationship between occupation (Worker, Officer, Housewife) and garden furniture purchase during the COVID-19 pandemic. Looking at the garden furniture purchasing preferences, the highest purchasing occupation group was the officer group with $69.2 \%$. The highest rate among those who replied "If I had a garden or a terrace, I would buy" is the housewife group with 52.6\% (Table 5).

According to our statistical analysis (Chi-Square Tests), it was found that there was a significant relationship between the profession and the desire to renew their living spaces as a result of long time spent at home during the COVID-19 pandemic. Considering the desire to renew living spaces, the rate of increase among officers is highest with $60.6 \%$, while this rate is $29.6 \%$ for workers, and it is seen that housewives want to renew their living space as $9.9 \%$ (Table 6).

According to our statistical analysis (Chi-Square Tests), which material (wood / plastic) is preferred in terms of health and its relation with marital status was questioned. Although there is no statistically significant relationship, it has been determined that the rate of choosing wooden garden furniture in women is high (Table 7). 


\section{Education Status}

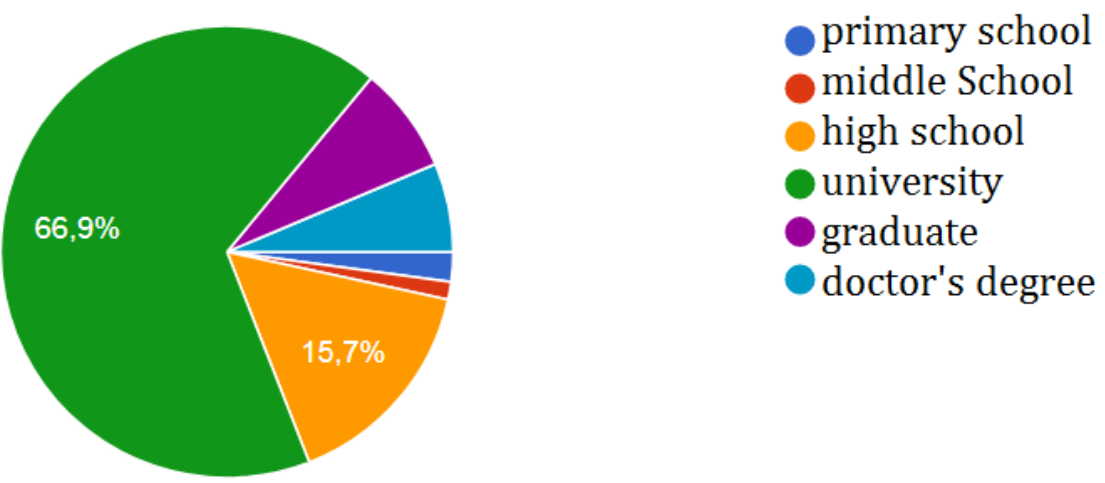

Fig. 1. Education Status

When we examine the educational status of our survey participants; the most participants are university graduates as 66.9\% (316), followed by high school graduates as $15.7 \%$ (74), and 1.3\% (6) secondary school graduates (Figure 1).

While the majority of our survey participants $(61.9 \%)$ did not change their interest in garden furniture during the Covid-19 pandemic, $28.4 \%$ stated that their interest increased and 9.7\% stated that their interest decreased (Figure 2).

How did your interest in Garden Furniture change during the COVID-19 pandemic?

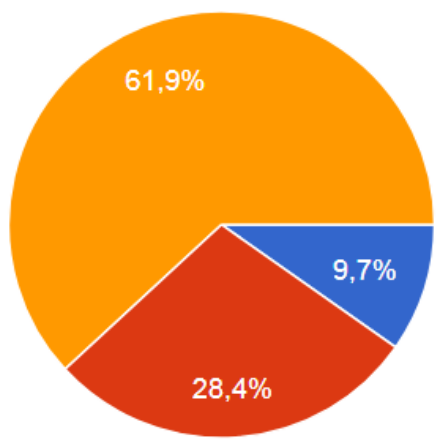

decreased

increased

stay the same

Fig. 2. How did you interest in Garden Funniture during de COVID-19 pandemic?

$60.2 \%$ of our survey participants stated that as a result of long time spent at home during the COVID-19 pandemic, their desire to renew their living spaces increased, for $36.9 \%$ it did not change and for $7 \%$ it decreased (Figure 3).

$81.4 \%$ of our survey participants stated that as a result of long time spent at home during the COVID-19 pandemic, their interest in nature / open spaces increased, for $16.9 \%$ it did not change and for $4 \%$ it decreased (Figure $4)$. 
As a result of the long time you spent at home during the COVID-19 pandemic, in what direction did you want to renew your living spaces?
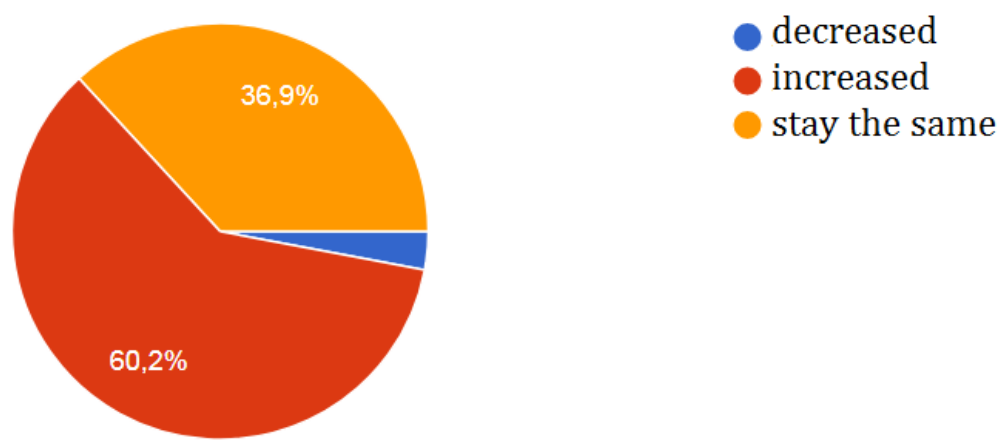

Fig. 3. In what direction did you want to renew you living spaces?

How has your interest in nature changed due to the long time you spent at home during the COVID-19 pandemic?

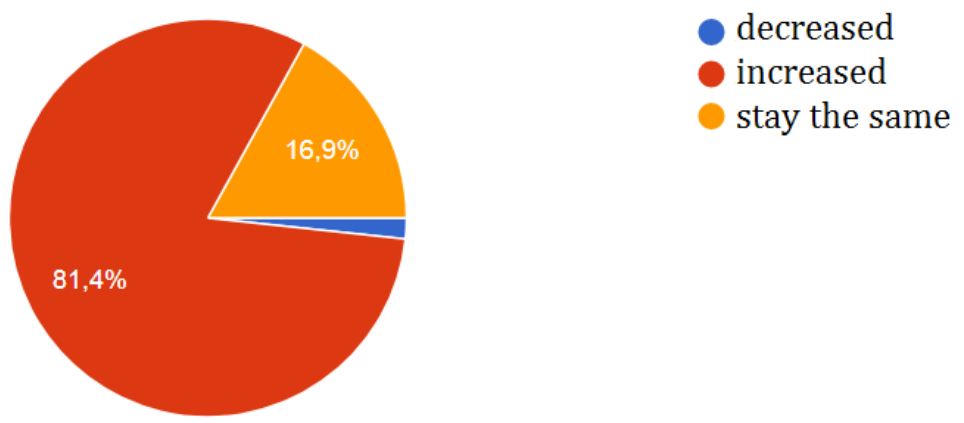

Fig. 4 How has your interest in nature changed due to the long time you spent at home during the Covid-19 pandemic?

Due to restrictions on social activities during COVID-19; It has been revealed that consumers prefer garden furniture for reasons such as the ease of carrying, being comfortable, functionality, resistance to physical (moisture, water absorption etc.) and mechanical (impact, abrasion and scratch) factors, and the longevity of the furniture (Figure 5). 


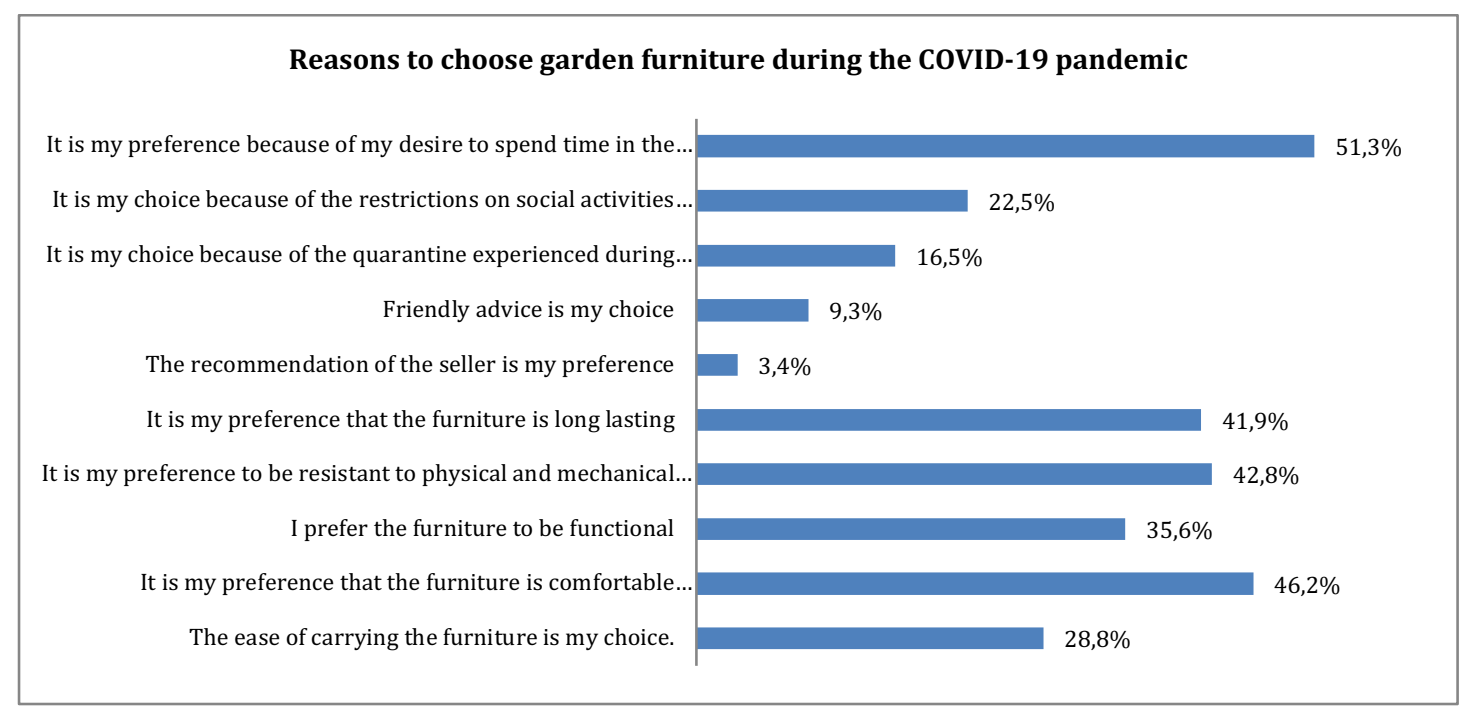

Figure 5.

The results showed that; $49,2 \%$ of the participants want to spend time in the garden, $39,4 \%$ want to spend time outdoor and $29,2 \%$ on the balcony, after COVID-19 pandemic period. As can be understood from the statistical data, consumers' interest in nature and open space will increase in the period after the pandemic (Figure 6).

\section{Conclusion}

The Covid-19 pandemic has affected the society globally. People had to stay in quarantine for long periods of time. Therefore, interest in park and garden furniture has increased. During COVID-19, due to the restrictions imposed on social activities, people were questioned about what aspects of furniture they pay attention to, and as a result, it was revealed that consumers preferred furniture with ease of transportation, comfort, functionality, durability and longevity. It is obvious that pandemics such as Covid-19, which affect the entire world, also affect the preferences of consumers. Although the pandemic period still continues, it's certain that people desire to spend time in the garden, on the balcony, on the terrace or outdoors. 


\section{In which areas do you intend to spend more time after the COVID-19 pandemic?}

There will be no changes in the preferences

$11,9 \%$

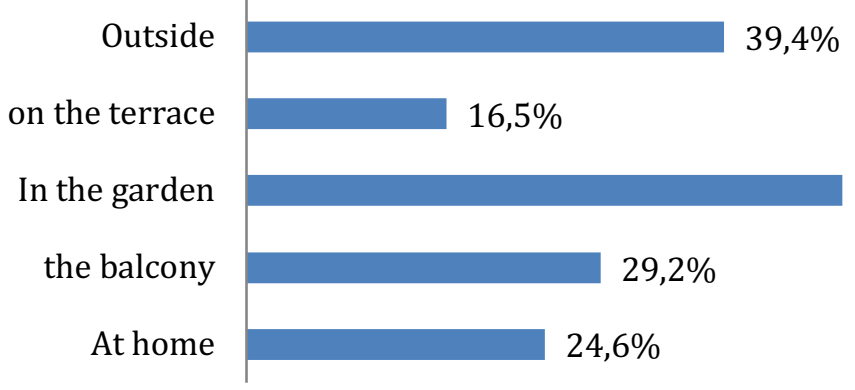

Figure 6.

Table 1: Gender - Desire of House Renovation Correlation

Gender X Desire of house renovation correlation Crosstabulation

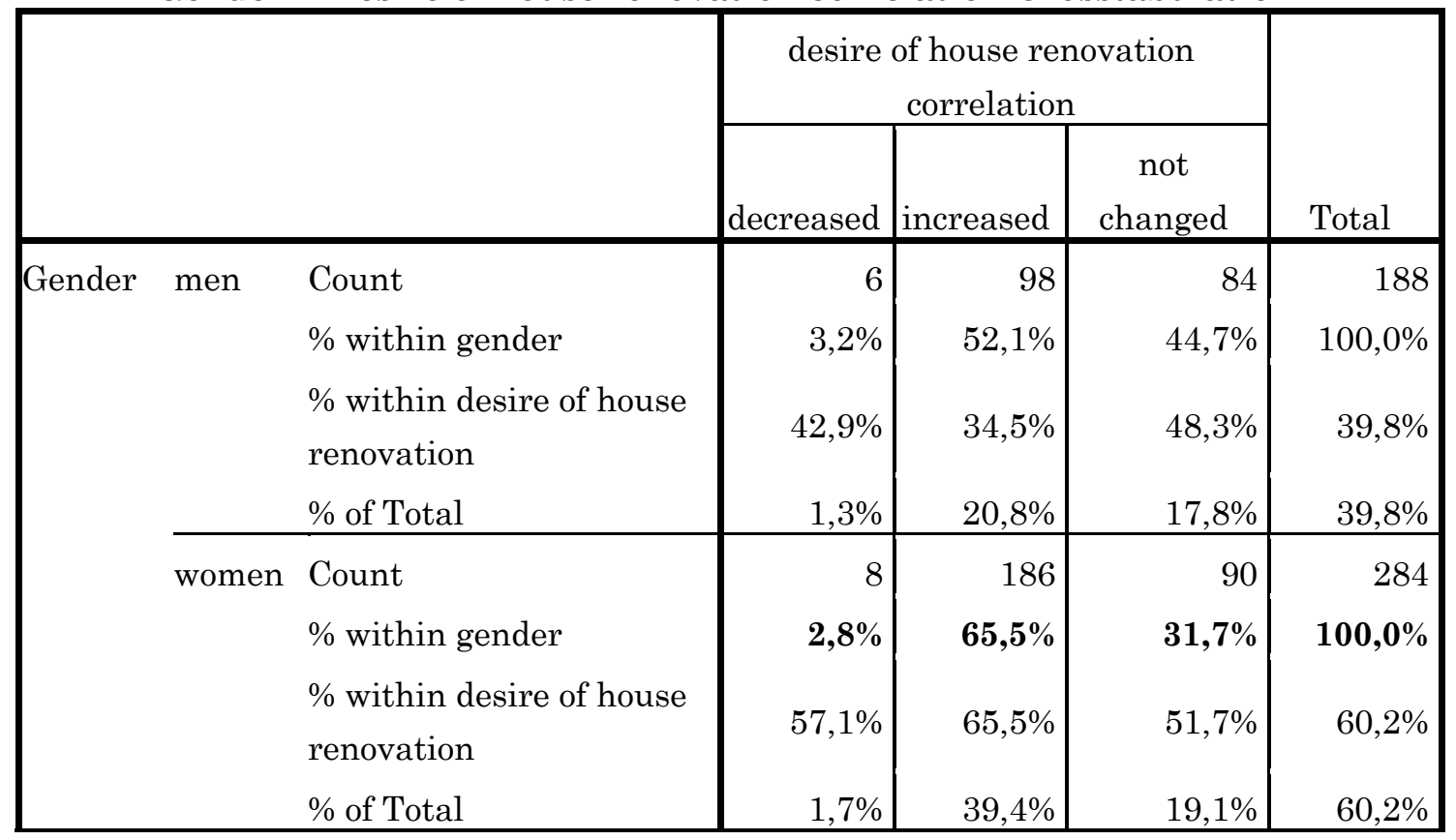

Chi-Square Tests

\begin{tabular}{|c|c|c|c|}
\hline & Value & $\mathrm{df}$ & $\begin{array}{c}\text { Asymp. Sig. } \\
\text { (2-sided) }\end{array}$ \\
\hline Pearson Chi-Square & $8,590^{\mathrm{a}}$ & 2 & ,014 \\
\hline Likelihood Ratio & 8,553 & 2 &, 014 \\
\hline Linear-by-Linear & 6340 & 1 & 012 \\
\hline Association & & & \\
\hline $\mathrm{N}$ of Valid Cases & 472 & & \\
\hline
\end{tabular}

a. 0 cells $(0,0 \%)$ have expected count less than 5 . The minimum expected count is 5,58 . 
Table 2: Gender - Interest in Nature

Gender X Interest in nature Crosstabulation

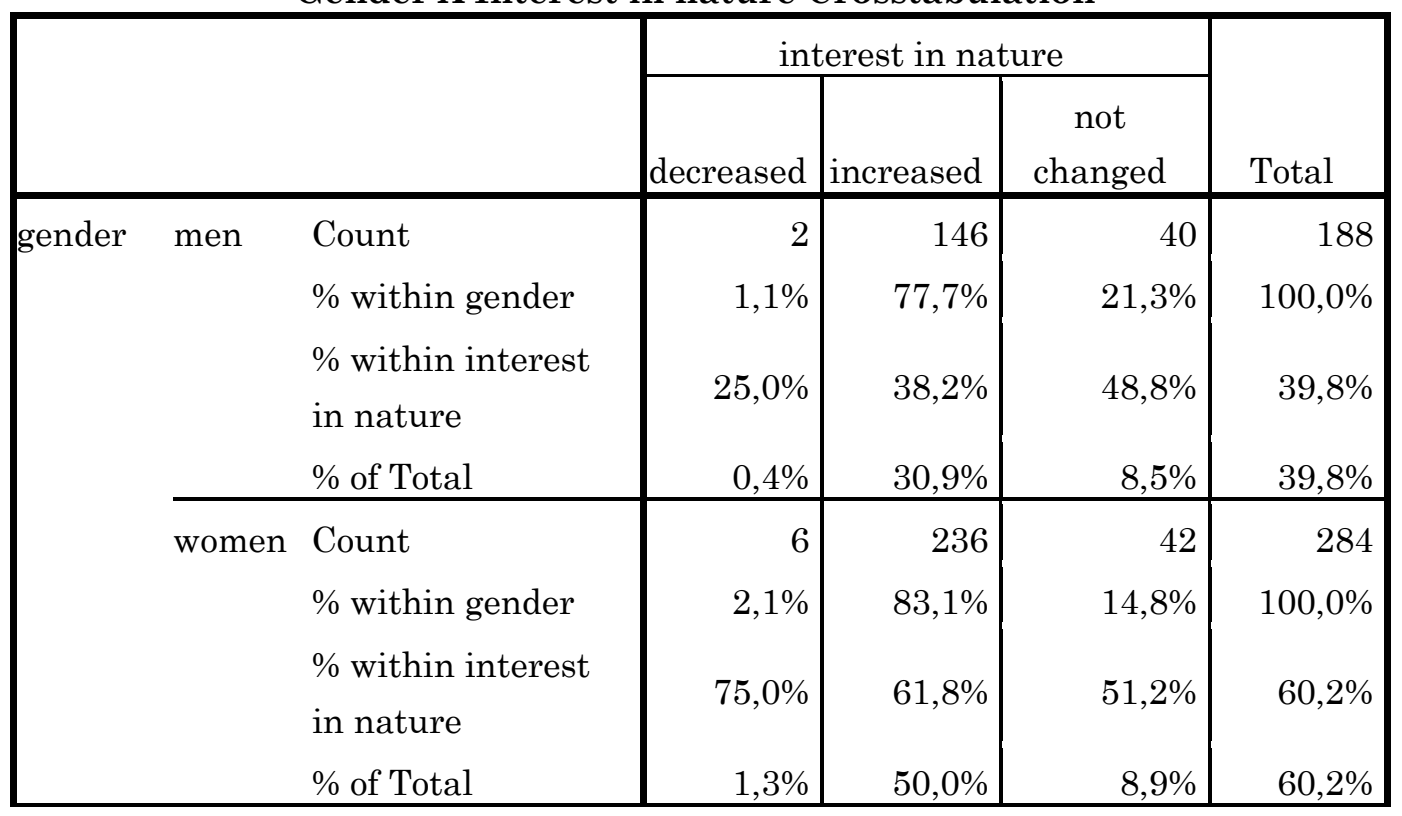

Chi-Square Tests

\begin{tabular}{|c|c|c|c|}
\hline & Value & $\mathrm{df}$ & $\begin{array}{l}\text { Asymp. Sig. } \\
\text { (2-sided) }\end{array}$ \\
\hline Pearson Chi-Square & $3,888^{\mathrm{a}}$ & 2 & 143 \\
\hline Likelihood Ratio & 3,884 & 2 & 143 \\
\hline $\begin{array}{l}\text { Linear-by-Linear } \\
\text { Association }\end{array}$ & 3,860 & 1 & ,049 \\
\hline $\mathrm{N}$ of Valid Cases & 472 & & \\
\hline
\end{tabular}

a. 2 cells $(33,3 \%)$ have expected count less than 5 . The minimum expected count is 3,19 .

Table 3: Marital Status - Interest in Nature Marital status X Interest in nature Crosstabulation

\begin{tabular}{|c|c|c|c|c|c|c|}
\hline & \multicolumn{3}{|c|}{ interest in nature } & \multirow[b]{2}{*}{ Total } \\
\hline & & & decreased & increased & $\begin{array}{c}\text { not } \\
\text { changed }\end{array}$ & \\
\hline \multirow[t]{6}{*}{ Marial status } & \multirow{4}{*}{$\begin{array}{l}\text { marrie } \\
\text { d }\end{array}$} & Count & 6 & 244 & 42 & 292 \\
\hline & & $\%$ within marial status & $2,1 \%$ & $83,6 \%$ & $14,4 \%$ & $100,0 \%$ \\
\hline & & $\begin{array}{l}\% \text { within interest in } \\
\text { nature }\end{array}$ & $75,0 \%$ & $63,9 \%$ & $51,2 \%$ & $61,9 \%$ \\
\hline & & $\%$ of Total & $1,3 \%$ & $51,7 \%$ & $8,9 \%$ & $61,9 \%$ \\
\hline & \multirow[t]{2}{*}{ single } & Count & 2 & 138 & 40 & 180 \\
\hline & & _\% within marial status & $1,1 \%$ & $76,7 \%$ & $22,2 \%$ & $100,0 \%$ \\
\hline
\end{tabular}




\begin{tabular}{|l|r|r|r|r|}
\hline \begin{tabular}{l|r|r|r|} 
\% within interest in \\
nature
\end{tabular} & $25,0 \%$ & $36,1 \%$ & $48,8 \%$ & $38,1 \%$ \\
\% of Total & $0,4 \%$ & $29,2 \%$ & $8,5 \%$ & $38,1 \%$ \\
\hline
\end{tabular}

Table 4: Location - Interest in Garden Furniture

Location X Interest in garden furniture Crosstabulation

\begin{tabular}{|c|c|c|c|c|c|c|}
\hline & & & interest & in garden & Irniture & \\
\hline & & & decreased & increased & $\begin{array}{c}\text { not } \\
\text { changed }\end{array}$ & Total \\
\hline location & city center & Count & 34 & 96 & 198 & 328 \\
\hline & & $\%$ within location & $10,4 \%$ & $29,3 \%$ & $60,4 \%$ & $100,0 \%$ \\
\hline & & $\begin{array}{l}\% \text { within interest in } \\
\text { garden furniture }\end{array}$ & $73,9 \%$ & $72,7 \%$ & $67,3 \%$ & $69,5 \%$ \\
\hline & & $\%$ of Total & $7,2 \%$ & $20,3 \%$ & $41,9 \%$ & $69,5 \%$ \\
\hline & smaller & Count & 8 & 32 & 74 & 114 \\
\hline & districts & $\%$ within location & $7,0 \%$ & $28,1 \%$ & $64,9 \%$ & $100,0 \%$ \\
\hline & & $\begin{array}{l}\% \text { within interest in } \\
\text { garden furniture }\end{array}$ & $17,4 \%$ & $24,2 \%$ & $25,2 \%$ & $24,2 \%$ \\
\hline & & $\%$ of Total & $1,7 \%$ & $6,8 \%$ & $15,7 \%$ & $24,2 \%$ \\
\hline & rural & Count & 4 & 4 & 22 & 30 \\
\hline & areas & $\%$ within location & $13,3 \%$ & $13,3 \%$ & $73,3 \%$ & $100,0 \%$ \\
\hline & & $\begin{array}{l}\% \text { within interest in } \\
\text { garden furniture }\end{array}$ & $8,7 \%$ & $3,0 \%$ & $7,5 \%$ & $6,4 \%$ \\
\hline & & $\%$ of Total & $0,8 \%$ & $0,8 \%$ & $4,7 \%$ & $6,4 \%$ \\
\hline
\end{tabular}

Chi-Square Tests

\begin{tabular}{|c|c|c|c|}
\hline & Value & $\mathrm{df}$ & $\begin{array}{l}\text { Asymp. Sig. } \\
\text { (2-sided) }\end{array}$ \\
\hline Pearson Chi-Square & $4,801^{\mathrm{a}}$ & 4 & ,308 \\
\hline Likelihood Ratio & 5,374 & 4 & 251 \\
\hline Linear-by-Linear & 1,479 & 1 &, 224 \\
\hline N of Valid Cases & 472 & & \\
\hline
\end{tabular}

a. 1 cells $(11,1 \%)$ have expected count less than 5 . The minimum expected count is 2,92 . 
Table 5: Vocation - Furniture Purchase Correlation

Vocation X Furniture Purchase Correlation Crosstabulation

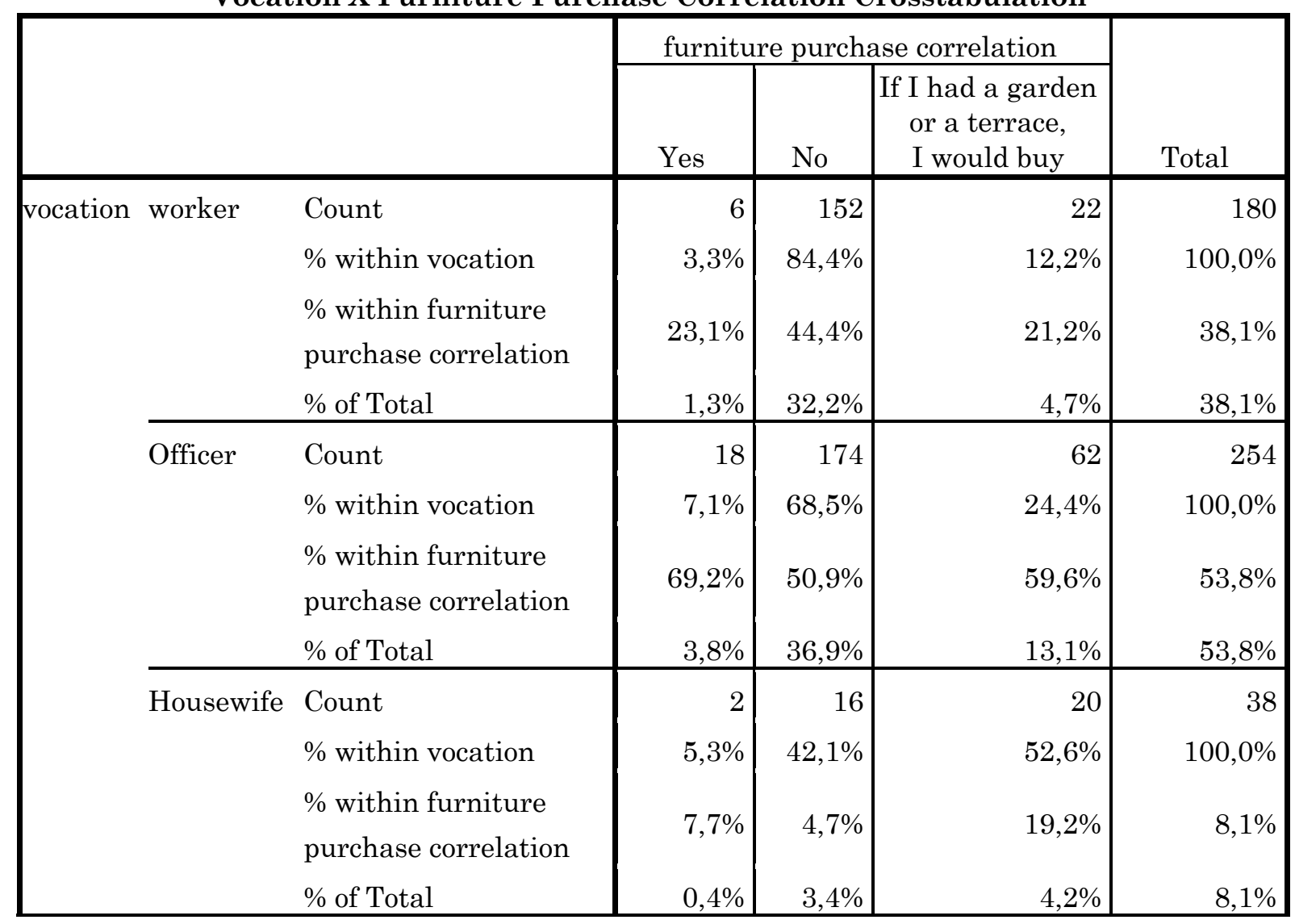

Chi-Square Tests

\begin{tabular}{|c|c|c|c|}
\hline & Value & $\mathrm{df}$ & $\begin{array}{c}\text { Asymp. Sig. } \\
\text { (2-sided) }\end{array}$ \\
\hline Pearson Chi-Square & $36,309^{a}$ & 4 & ,000 \\
\hline Likelihood Ratio & 34,097 & 4 & ,000 \\
\hline Linear-by-Linear & 14,881 & 1 & ,000 \\
\hline $\begin{array}{l}\text { Association } \\
\text { N of Valid Cases }\end{array}$ & 472 & & \\
\hline
\end{tabular}

a. 1 cells $(11,1 \%)$ have expected count less than 5 . The minimum expected count is 2,09 . 
Table 6: Vocation - Desire of House Renovation Correlation

Vocation X Desire of House Renovation Correlation Crosstabulation

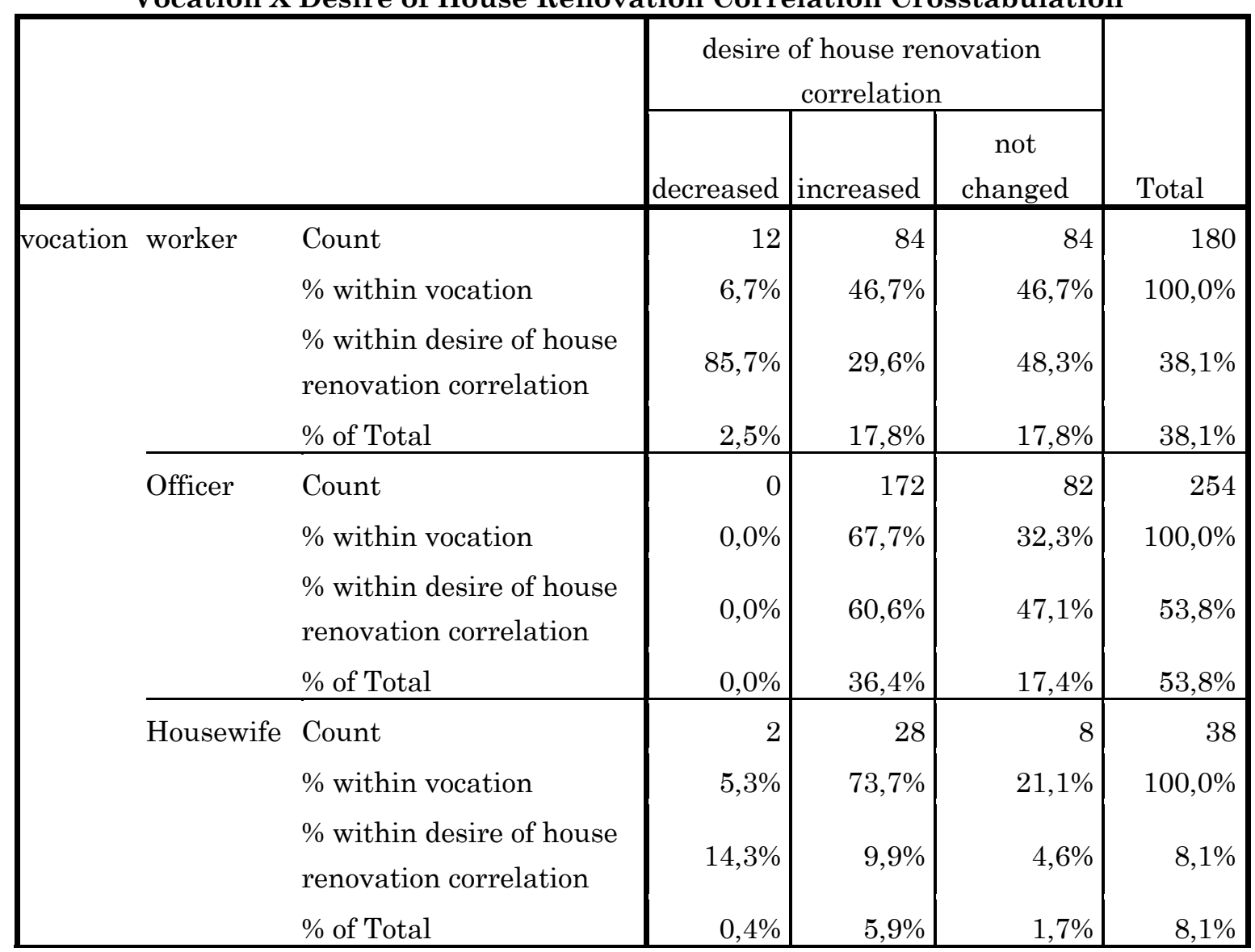

Chi-Square Tests

\begin{tabular}{|c|c|c|c|}
\hline & Value & $\mathrm{df}$ & $\begin{array}{l}\text { Asymp. Sig. } \\
\text { (2-sided) }\end{array}$ \\
\hline Pearson Chi-Square & $34,247^{\mathrm{a}}$ & 4 & ,000 \\
\hline Likelihood Ratio & 39,918 & 4 & ,000 \\
\hline $\begin{array}{l}\text { Linear-by-Linear } \\
\text { Association }\end{array}$ & 6,411 & 1 & ,011 \\
\hline $\mathrm{N}$ of Valid Cases & 472 & & \\
\hline
\end{tabular}

a. 1 cells $(11,1 \%)$ have expected count less than 5 . The

minimum expected count is 1,13 . 
Table 7: Marital Status - Which Material Do You Think Is Healthy? Marital status X Which Material do you think is healthy? Crosstabulation

\begin{tabular}{|c|c|c|c|c|c|}
\hline & & & $\begin{array}{r}\text { Which Mat } \\
\text { think is }\end{array}$ & $\begin{array}{l}\text { al do you } \\
\text { lthy? }\end{array}$ & \\
\hline & & & plastic & wood & Total \\
\hline Marital status & married & Count & 50 & 242 & 292 \\
\hline & & $\%$ within Marital status & $17,1 \%$ & $82,9 \%$ & $100,0 \%$ \\
\hline & & $\begin{array}{l}\% \text { within which one is } \\
\text { healthy? }\end{array}$ & $55,6 \%$ & $63,4 \%$ & $61,9 \%$ \\
\hline & & $\%$ of Total & $10,6 \%$ & $51,3 \%$ & $61,9 \%$ \\
\hline & single & Count & 40 & 140 & 180 \\
\hline & & $\%$ within Marital status & $22,2 \%$ & $77,8 \%$ & $100,0 \%$ \\
\hline & & $\begin{array}{l}\% \text { within which one is } \\
\text { healthy? }\end{array}$ & $44,4 \%$ & $36,6 \%$ & $38,1 \%$ \\
\hline & & $\%$ of Total & $8,5 \%$ & $29,7 \%$ & $38,1 \%$ \\
\hline
\end{tabular}

Chi-Square Tests

\begin{tabular}{|c|c|c|c|c|c|}
\hline & Value & $\mathrm{df}$ & $\begin{array}{l}\text { Asymp. Sig. } \\
\text { (2-sided) }\end{array}$ & $\begin{array}{l}\text { Exact Sig. (2- } \\
\text { sided) }\end{array}$ & $\begin{array}{l}\text { Exact Sig. (1- } \\
\text { sided) }\end{array}$ \\
\hline Pearson Chi-Square & $1,876^{\mathrm{a}}$ & 1 & 171 & \multirow{7}{*}{ 185 } & \multirow{7}{*}{, 106 } \\
\hline Continuity Correction ${ }^{b}$ & 1,560 & 1 & 212 & & \\
\hline Likelihood Ratio & 1,851 & 1 & 174 & & \\
\hline Fisher's Exact Test & & & & & \\
\hline Linear-by-Linear & 1870 & 1 & 171 & & \\
\hline Association & 1,872 & 1 &, 171 & & \\
\hline $\mathrm{N}$ of Valid Cases & 472 & & & & \\
\hline
\end{tabular}

a. 0 cells $(, 0 \%)$ have expected count less than 5 . The minimum expected count is 34,32 .

b. Computed only for a $2 \times 2$ table

\section{NOTES}

${ }^{1}$ Roujian Lu and others, "Genomic Characterisation and Epidemiology of 2019 Novel Coronavirus: Implications for Virus Origins and Receptor Binding," The Lancet, 395.10224 (2020), 565-74.

2 Anthony S Fauci, H Clifford Lane, and Robert R Redfield, "Covid-19-Navigating the Uncharted" (Mass Medical Soc, 2020). Seth G. Benzell, Avinash Collis, and Christos Nicolaides, "Rationing Social Contact during the COVID-19 Pandemic: Transmission Risk and Social Benefits of US Locations," Proceedings of the National Academy of Sciences of the United States of America, 117.26 (2020), 14642-44 $<$ https://doi.org/10.1073/pnas.2008025117>.

${ }^{3}$ Shuquan Chen and George A Bonanno, "Psychological Adjustment during the Global Outbreak of COVID-19: A Resilience Perspective," Psychological Trauma: Theory, Research, Practice, and Policy, 12.S1 (2020), S51.

${ }^{4}$ Jianyin Qiu and others, "A Nationwide Survey of Psychological Distress among Chinese People in the COVID-19 Epidemic: Implications and Policy Recommendations," General Psychiatry, 33.2 (2020).

${ }^{5}$ (Sai et al., 2020) 
${ }^{6}$ Mustafa Zor, "Bahçe Oturma Mobilya Konstrüksiyonlarında Isıl İşlem Uygulanmış Ağaç Malzemenin Kullanım İmkanlarının Mühendislik Tasarımı Yaklaşımıyla İincelenmesi," Bartın Üniversitesi, Orman Endüstri Mühendisliği, Yüksek Lisans Tezi, 2011.

${ }^{7}$ Ibídem.

${ }^{8}$ Ibídem.

${ }^{9} \mathrm{Lu}$ Xiaomeng, "An Analysis to the Design of Garden Furniture [J]," Furniture \& Interior Design, 6 (2014).

${ }^{10}$ Zor. Op. Cit.

${ }^{11}$ Willem Van Dis, "Garden Furniture Cushions with Exchangeable Cover" (Google Patents, 1994).

${ }^{12}$ Liron Hartman, Yaacov Kurtz, and Efraim Haimoff, "Garden Furniture" (Google Patents, 2014).

${ }^{13}$ Zor. Op. Cit.

${ }^{14}$ Megep, 'Bahçe Mobilyası', Mesleki Eğitim ve Mesleki Eğitimi Geliştirme Projesi (Megep), Mobilya ve Iç Mekan Tasarımı 543M00133, 2011.

${ }^{15}$ Zor. Op. Cit. Megep, 'Bahçe Mobilyası'. Op. Cit.

${ }^{16}$ Frank BGJM Krake, "Garden Chair" (Google Patents, 2005).

${ }^{17}$ L Fedrizzi and others, "Corrosion Study of Industrial Painting Cycles for Garden Furniture," Progress in Organic Coatings, 46.1 (2003), 62-73.

${ }_{18}$ Megep, 'Bahçe Mobilyası'. Op. Cit.

${ }^{19}$ Zor. Op. Cit. Hartman, Kurtz, and Haimoff. Op. Cit.

${ }^{20}$ Zor. Op. Cit. Vance P Braxton III, "Swing Seat'"(Google Patents, 1992).

${ }^{21}$ Megep, 'Bahçe Mobilyası'. Op. Cit.

${ }^{22}$ Zor. Op. Cit.

${ }^{23}$ Zor. Op. Cit.

${ }^{24}$ Michael Stachowitsch, "Furniture and Furnishings," in The Beachcomber's Guide to Marine Debris (Springer, 2019), pp. 201-17.

${ }^{25}$ Oliver Joen-an Ma, 'Umbrella Assembly with Tilt Adjustment' (Google Patents, 2010).

${ }^{26}$ Stachowitsch.

${ }^{27} \mathrm{~J}$ L Montero, M C Salas, and P Mellado, 'Hydroponic Pergola as an Example of Living Furniture in Urban Landscape', in II International Conference on Landscape and Urban Horticulture 881, 2009, pp. 355-58.

${ }^{28}$ Charles Thonger, The Book of Garden Furniture (Applewood Books, 2008).

${ }^{29}$ Montero, Salas, and Mellado. Op. Cit.

${ }^{30}$ Megep, "Bilgisayarla Bahçe Mobilyasi Çizimi," Mesleki Eğitim ve Mesleki Eğitimi Geliştirme Projesi (Megep), Mobilya ve İç Mekan Tasarımı, 2013.

${ }^{31}$ Charbel Nassif, "Transformable Furniture Unit" (Google Patents, 2016).

${ }^{32}$ Zor. Op. Cit.

Received: $2020-12-17$

Revised: 2020-12-30

Accepted: 2021-02-02 